\title{
Growth and development of bulls of different types of productivity
}

\author{
Alexandr Donetskikh ${ }^{1}$, Styapas Grikshas ${ }^{2}$, Olga Pastukh $^{2}$, Polina Korenevskaya², Ruslan Kertiev ${ }^{2}$ \\ ${ }^{1}$ VNIHI-branch of the Federal State Budgetary Scientific Institution "FSC Food Systems named after V. Gorbatov “RAS”", \\ Kostyakova st., 12, Moscow, 127422, Russia \\ ${ }^{2}$ Russian State Agrarian University - Moscow Agricultural Academy named after K.A. Timiryazev, Timiryazevskaya st., 49, Moscow, \\ 127550, Russia
}

\begin{abstract}
The article provides data on the weight growth of bulls of different types of productivity. The growth and development of Black-and-white, Simmental and Aberdeen-Angus bulls were studied during the period of their rearing and feeding. The change in live weight was established, the dynamics and growth rate of the studied bulls were calculated depending on the breed and type of productivity. The research results showed that the Aberdeen-Angus bulls had the highest live weight during fattening - $485.2 \mathrm{~kg}$, which was significantly higher than that of the Black-and-White and Simmental breeds by $68.7 \mathrm{~kg}(\mathrm{p}<0.001)$ or $14.0 \%$ and $19.7 \mathrm{~kg}$ ( $\mathrm{p}<0.01$ ), or $4.1 \%$ respectively. The average daily gain in live weight from birth to 15 months of age in bulls of Black-and-white, Simmental and Aberdeen Angus breeds amounted to 860.0; 965.1 and 1022.7 grams respectively. In the Aberdeen-Angus cattle, in comparison with the Black-andWhite and Simmental breeds, the value of this indicator was significantly higher, by $162.7 \mathrm{~g}$, or $15.9 \%$ (p $<0.001$ ) and $57,6 \mathrm{~g}$, or $5.6 \%(\mathrm{p}<0.01)$ respectively. It was found that the type of productivity had a certain effect on the dynamics of live weight, the intensity of growth and development of animals.
\end{abstract}

\section{Introduction}

Currently, there is an increase in the prices of feed and other ingredients that make up a significant part of the cost of meat products. At the same time, prices for meat products are either stable or fall as a result of increased competition. In pig and poultry husbandry, this is offset to some extent by increased profitability, but this is not the case for beef production. In addition, the consumption of beef is declining.

One of the priority tasks of the development of the agro-industrial complex of the Russian Federation under current conditions is to provide the population with fullfledged meat and meat products with a high content of amino acids, fats, all necessary vitamins and microelements. Therefore, in the coming years, the development of domestic beef cattle breeding will become one of the strategic directions $[1,2]$.

As noted by I.M. Dunin, H.A. Amerkhanov, A.A. Kochetkov, the main result of the concept outlined in the Forecast of an increase in beef production and the development of beef cattle breeding in Russia for 20082012 and for the period up to 2022, approved by the Minister of Agriculture of the Russian Federation on July 12, 2007, will be the creation of a basis for the formation of a large-scale industry of specialized beef cattle. It will be capable in the long term until 2022 to compensate for the lack of a fattening contingent from dairy herds (due to the stabilization of the number of dairy cows) and to bring the share of beef from specialized beef cattle from $2 \%$ in 2007 to $35-40 \%$ in 2022. It is also planned to bring the production of beef to 4.0 million tons in slaughter weight by 2022 [3]. This will help reduce dependence on imports for supplying the country's population with beef by increasing its own production.

The study has shown that the productive and biological qualities of animals directly depend on the level and nature of metabolic processes in the body of animals, rations of feeding and maintenance, as well as on breed characteristics. The high adaptive and productive potential of the Simmental and Aberdeen Angus breeds makes it possible to use them for the sustainable development of beef cattle breeding [5, 6, 7].

As indicated by I.P. Prokhorov et al. [8], intensive rearing and fattening of Black-and-white and Simmental bulls and their crosses with Aberdeen-Angus, Charolais, Hereford and Limousin breeds contributed to an increase in beef production and its qualitative improvement. Crossbreeds of the Black-and-white breed with the Charolais, Hereford and Limousine breeds had increased growth energy, while their live weight at 15 months of age exceeded the weight of the Black-and-white peers by $39.1 \mathrm{~kg}(\mathrm{P}<0.001), 12.0 \mathrm{~kg}(\mathrm{P}<0.05)$ and $22.5 \mathrm{~kg}(\mathrm{P}$ $<0.001)$. Foreign researchers obtained similar results.

Growth and development play an important role in the formation of the meat productivity of animals. K.B.

\footnotetext{
*Corresponding author: korenevskaya.pa@rgau-msha.ru
} 
Svechin, (1976) accurately revealed the essence of the concepts of growth and development. He believed that the individual development of an animal organism includes two main points: the growth or accumulation of live weight and the differentiation or division of a relatively homogeneous live weight into heterogeneous organs and tissue systems. According to this author, the growth of animals is one of the aspects of the individual development of an organism, which inherits from its ancestors the ability to develop in a certain way and respond to the effects of the external environment, forming an individuality inherent only in it, including the features of its constitution, productivity, exterior, temperament and vitality. At the same time, the quantitative aspect of ontogenesis manifests itself in the growth of the organism without significant changes in its physiological and morphological properties, while the qualitative aspect reflects the development of new cells and tissues.

In this regard, the cultivation of beef cattle breeds more efficiently pays off the feed by weight gain, is characterized by a high slaughter yield, and gives high quality meat in comparison with the cultivation of dairy breeds or mixed breeds of productivity. The biological usefulness of beef is influenced by the breed, sex, age of the animal, its fatness, the conditions of feeding and keeping the animals, as well as the proportion of muscle mass and fat in the cut.

Intensively reared young animals at the age of 15 months are distinguished by good development and are characterized by a high water content $(60-75 \%)$, protein (18-21\%) and a low fat content (10-20\%), as well as an ash content of about $1 \%$. The meat of adult animals is characterized by a higher fat content and a lower protein content, which lowers its biological value $[3,6]$. The protein content in the carcasses of adult animals is 17$20 \%$, water $-58-67 \%$, fat $-11-30 \%$ and ash $-0.9-1.1 \%$. Even more significant differences in chemical composition are observed between different parts of the carcasses and muscles.

As part of the development of modern agriculture, special attention should be paid to the creation of herds of animals capable of ensuring high productivity and meat yield in a specific climatic zone and a specific technology of reproduction and cultivation. However, the slaughter and meat qualities of calf bulls of the Black-and-White, Aberdeen-Angus and Simmental breeds have not been sufficiently studied in the conditions of the Non-Black Earth Zone of the Russian Federation.

The goal of the research was to study the change in live weight, the dynamics of average daily gains and the growth rate of bulls of Black-and-white, Simmental and Aberdeen Angus breeds of cattle.

\section{Materials and methods}

The experimental part of the study was carried out in 2016-2020 on the farm of LLC "Favorit", Tula region, on the farm in a specially equipped for slaughter. The carcasses of the bulls were assessed by the degree of deposition of subcutaneous fat. Only bulls were selected for rearing at the feedlot. Thus, the objects of the study were purebred bulls of the Black-and-White, Simmental and Aberdeen-Angus breeds.

From birth to 6 months of age, Black-and-white and Simmental bulls were kept according to the technology of raising dairy cattle - in individual houses on feeding grounds, Aberdeen Angus - according to the technology of raising beef cattle on suckling according to the "cowcalf" system in pasture conditions. Upon reaching the age of 6 months, groups of 10 animals per group were formed.

From 6 to 15 months of age, they were raised under identical conditions of feeding and keeping on a walking-fodder area using fodder of their own production. Feeding type is silage-haylage (hay, straw, silage, haylage and grain-mixture) according to detailed norms and rations for feeding young fattening stock. The level of feeding of experimental animals was provided in accordance with the norms and rations of feeding of farm animals (2003) to obtain average daily gains of $1000-1100 \mathrm{~g}$ and achieve a live weight of $450-500 \mathrm{~kg}$ at 15 months of age. The feeding and keeping conditions of the animals in the groups were identical.

Live weight and growth rate of bulls of the studied breeds were determined at $6,8,10,12$ and 15 months of age. The dynamics of average daily gains after 6 months of age was determined every 2-3 months. The growth rate of bulls was defined as the ratio of live weight at certain age periods to weight at birth.

The left half-carcass of the experimental animals after 24 hours of cooling in the refrigeration chamber was subjected to a collapse and a vein to determine the absolute and relative mass of the pulp, bones and tendons. The morphological and chemical composition of carcasses and their measurements was determined in accordance with the "Wachnil Methodical Recommendations for assessing meat productivity and quality of cattle meat." Biometric processing of the data was carried out in accordance with the guidelines for the design of measurement results using the Microsoft Excel operating system. The reliability of the difference was accepted at the threshold of reliability B1 - 0.95 (the level of significance $P<0.05$ ).

The relative gain was determined by S. Brody's formula:

$$
\frac{(W t-W o) * 100}{\left(W t+W_{0}\right): 2}
$$

where Wo - initial mass, $\mathrm{kg}$; Wt - final mass, $\mathrm{kg}$

The slaughter weight is defined by the calculated method as the ratio of the pre-killing live mass of bulls to the mass of carcasses received after slaughter and multiply by $100 \%$.

Biometric data were processed according to the System of Applied Statistical and Mathematical Methods for Processing Experimental Data in Agriculture [9] using Microsoft Excel. Youngsters of the Black-andwhite breed, which are the most widespread in the Russian Federation, were used as a control. The level of significance of the difference between the groups of bulls for the studied indicators was determined on the 
basis of the criterion of reliability of the difference between the arithmetic means (td) using Student tables. The results of statistical processing were expressed as $M$ $\pm \mathrm{m}$, where $\mathrm{M}$ - meant the arithmetic mean, $\mathrm{m}$ - its error.

\section{Research results}

The highest live weight at birth belonged to Simmental calves $(31.2 \mathrm{~kg})$, the smallest - the Aberdeen-Angus $(25.0 \mathrm{~kg})$, which is associated with the biological characteristics of the Aberdeen-Angus cows. From 6 to 15 months of age, the live weight of Black-and-white,
Simmental and Aberdeen-Angus bulls increased by 263.0, 300.0 and $322.6 \mathrm{~kg}$ respectively (Table 1).

Thus, the Aberdeen Angus bulls had the highest live weight during fattening - $485.2 \mathrm{~kg}$, which is higher than that of the Black-and-White and Simmental breeds, respectively, by $68.7 \mathrm{~kg}$ ( $\mathrm{p}<0.001$ ), or $14.0 \%$ and 19.7 $\mathrm{kg}(\mathrm{p}<0.01)$, or $4.1 \%$. In terms of live weight, the bulls of the studied breeds belonged to the elite class. The average daily gain in live weight from birth to 15 months of age in bulls of the Black-and-white, Simmental and Aberdeen Angus cattle was 860.0, 965.1 and 1022.7 grams respectively (Table 2 ).

Table 1. Change in live weight according to age, $\mathrm{kg}(\mathrm{M} \pm \mathrm{m} ; \mathrm{n}=10$, in each group)

\begin{tabular}{|c|c|c|c|}
\hline \multirow{2}{*}{ Age (months) } & \multicolumn{3}{|c|}{ Groups / Breed } \\
\cline { 2 - 4 } & 1. Black-and-white & 2. Simmental & 3. Aberdeen-Angus \\
\hline At birth & $29.5 \pm 0.9$ & $31.2 \pm 1.1$ & $25.0 \pm 1.6^{1}$ \\
\hline 6 & $153.5 \pm 1.3$ & $165.5 \pm 3.6^{3}$ & $162.6 \pm 4.9^{3}$ \\
\hline 8 & $195.5 \pm 1.4$ & $219.1 \pm 4.2^{3}$ & $215.9 \pm 5.0^{3}$ \\
\hline 10 & $250.5 \pm 2.8$ & $285.0 \pm 4.9^{3}$ & $285.2 \pm 4.9^{3}$ \\
\hline 12 & $317.2 \pm 3.0$ & $354.5 \pm 4.8^{3}$ & $360.2 \pm 4.4^{3}$ \\
\hline 15 & $416.5 \pm 5.5$ & $465.5 \pm 3.5^{3}$ & $485.2 \pm 4.6^{3}$ \\
\hline
\end{tabular}

Notes: hereinafter: ${ }^{1}-\mathrm{P}<0.05 ;^{2}-\mathrm{P}<0.01 ;^{3}-\mathrm{P}<0.001$ in comparison with Black-and-white breed.

Table 2. Dynamics of average daily gains in live weight of experimental bulls, grams $(M \pm m ; n=10)$

\begin{tabular}{|c|c|c|c|}
\hline \multirow{2}{*}{ Age, months } & \multicolumn{3}{|c|}{ Groups / Breed } \\
\cline { 2 - 4 } & 1. Black-and-white & 2. Simmental & $764.4 \pm 8.9^{3}$ \\
\hline $0-6$ & $688.9 \pm 7.0$ & $743.3 \pm 8.8^{3}$ & $888.3 \pm 9.6^{3}$ \\
\hline $6-8$ & $700.0 \pm 6.5$ & $891.7 \pm 9.0^{3}$ & $1155.0 \pm 10.6^{3}$ \\
\hline $8-10$ & $916.7 \pm 8.9$ & $1016.7 \pm 10.2^{3}$ & $1250.0 \pm 12.7^{3}$ \\
\hline $10-12$ & $1111.7 \pm 10.7$ & $1158.3 \pm 12.3^{3}$ & $1388.9 \pm 14.2^{3}$ \\
\hline $12-15$ & $1103.3 \pm 12.8$ & $1233.3 \pm 11.5^{3}$ & $1022.7 \pm 11.5^{3}$ \\
\hline $0-15$ & $860.0 \pm 10.7$ & $965.1 \pm 10.6^{3}$ & \\
\hline
\end{tabular}

In the Aberdeen Angus cattle, in comparison with the Black-and-White and Simmental breed, the value of this indicator was higher, respectively, by $162.7 \mathrm{~g}$, or $15.9 \%$ ( $\mathrm{p}<0.001)$ and $57.6 \mathrm{~g}$, or $5.6 \%(\mathrm{p}<0.01)$. Thus, the Aberdeen Angus and Simmental bulls were characterized by a higher growth rate in comparison with the Black-and-White bulls.

The growth rate of bulls of the studied breeds was determined from birth in different periods of rearing. The highest growth rate in bulls was obtained from birth to 6 months of age from 135.5 - black-and-white bulls to 146.6 - Aberdeen Angus.

From birth to 6 months of age, from 6 to 8 months, from 8 to 10 months, and $12-15$ months the age growth rate was, respectively, $146.6 ; 28.2 ; 27.7 ; 29.3$, which is
$7.6 \%, 14.5 \%, 10.8 \%$ and $7.5 \%$ higher than in the Blackand-white bulls (Fig. 1). For the entire period of rearing the growth rates of bulls of the Black-and-White, Aberdeen-Angus and Simmental breeds amounted to $173.5 ; 174.9$ and 180.4 respectively. Consequently, Aberdeen-Angus bulls had the highest growth rate for the entire rearing period.

Meat productivity and slaughter indicators allow to assess the quality and quantity of meat more fully in comparison with live mass and average daily growth indicators. After the slaughter the carcasses were classified as the first category of fatness due to the wellexpressed forms and pronounced fullness (the ratio of mass to length of the carcass, expressed in percentage). 


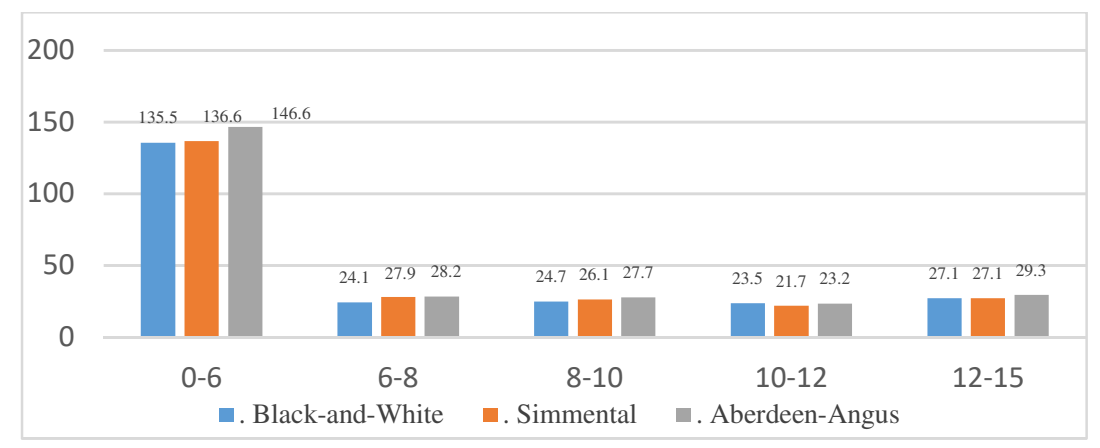

Fig. 1. Growth rate of bulls of the studied breeds $(M \pm m ; n=10)$

Table 3. Results of control slaughter of experimental calf bulls $(\mathrm{M} \pm \mathrm{m} ; \mathrm{n}=10)$

\begin{tabular}{|c|c|c|c|}
\hline \multirow{2}{*}{ Indicator } & \multicolumn{3}{|c|}{ Breed } \\
\cline { 2 - 4 } & $\begin{array}{c}\text { Black-and- } \\
\text { White }\end{array}$ & Simmental & $\begin{array}{c}\text { Aberdeen- } \\
\text { Angus }\end{array}$ \\
\hline $\begin{array}{c}\text { Pre- } \\
\text { slaughter } \\
\text { weight, kg }\end{array}$ & $401,2 \pm 6,21$ & $454,6 \pm 4,17$ & $484,7 \pm 5,37$ \\
\hline $\begin{array}{c}\text { Slaughter } \\
\text { weight, kg }\end{array}$ & $214,2 \pm 5,38$ & $288,6 \pm 6,12$ & $318,4 \pm 5,86$ \\
\hline $\begin{array}{c}\text { Slaughter } \\
\text { weight (in } \\
\text { percentage), } \\
\%\end{array}$ & $53,4 \pm 0,36$ & $63,5 \pm 0,46$ & $65,7 \pm 0,48$ \\
\hline
\end{tabular}

Analyzing the data in Table 3, it can be seen that the pre-slaughter live weight of black-and-white bulls was minimal $(401.2 \mathrm{~kg})$, while the pre-slaughter weight of Aberdeen-Angus bulls exceeded that of Black-andWhite and Simmental bulls by $73.5 \mathrm{~kg}$ and $30.1 \mathrm{~kg}$, respectively.

Slaughter weight was also the smallest in black-andwhite bulls $(214.2 \mathrm{~kg})$. The maximum slaughter weight was obtained for the Aberdeen-Angus group (318.4 kg), which exceeded the slaughter weight of the black-andwhite breed by $104.2 \mathrm{~kg}$, and the slaughter weight of the Simmental breed by $29.8 \mathrm{~kg}$.

A more complete indicator characterizing the outcome of the final product is the slaughter yield. The highest value of this indicator was obtained for bulls of the Aberdeen-Angus group - 65.7\%, which exceeded this indicator for bulls of the black-and-white breed group by $14.3 \%$, and for the group of Simmental bulls by $2.2 \%$.

Based on the presented data, it can be concluded that the Aberdeen-Angus calf bulls in their meat characteristics slightly exceed the indicators of the Simmental bulls and significantly exceed the indicators of the Black-and-White bulls.

\section{Conclusion}

In conclusion, it should be noted that under the conditions of "Favorit" LLC with moderate feeding using fodders of its own production, bulls of the Blackand-White, Simmental and Aberdeen-Angus breeds were born with a live weight of $29.5 \mathrm{~kg}, 31.2 \mathrm{~kg}$ and $25.0 \mathrm{~kg}$, respectively. At the same time, weaned at 180 days of age, they weighed $153.5 \mathrm{~kg}, 165.5 \mathrm{~kg}$ and $162.6 \mathrm{~kg}$ and by 15 months - $416.5 \mathrm{~kg}, 465.5 \mathrm{~kg}$ and $485.2 \mathrm{~kg}$, respectively.

The dynamics of average daily gains fluctuated markedly, reaching $1388.9 \mathrm{~g}$ in Aberdeen Angus by the age of 12-15 months. The growth and development of animals was influenced by the season and month of birth, conditions of keeping and feeding. Regardless of fluctuations in growth in different periods of rearing, bulls of the Simmental and Aberdeen Angus breeds reach the optimal slaughter live weight $(465-485 \mathrm{~kg})$ by 15 months of age.

The results of the control slaughter show that the difference in slaughter yield between the control (blackand-white breed) and Aberdeen-Angus bulls is $14.3 \%$, and it is $10.1 \%$ for the Simmental breed.

\section{References}

1. F. G. Kayumov, A. F. Shevhuzhev, Zootekhniya, 11 (2016)

2. I. V. Sazonova, KubSAU Journal, 83(09) (2012)

3. I. M. Dunin, Y. A. Amerhanov, A. A. Kochetkov, Dairy and beef cattle breeding, 8 (2007)

4. A. G. Doneckih, Achievements of science and technology of the agro-industrial complex, 4 (33) (2019)

5. S. A. Griksas, M. M. Shamidova, Ya. A. Yuldashbaeb, V. V. Kylintsev, N. I. Kylmakova, T. S. Kubatbekov, E. O. Rystsova, International Journal of Pharmaceutical Research, 10 (2018)

6. C. Avilés, A. Martínez, V. Domenech, F. Peña, Effect of feeding system and breed on growth performance, and carcass and meat quality traits in two continental beef breeds 107 (2015)

7. G. I. Ragimov, K. V. Zhuchaev, M. L. Kochneva, V. V. Gart, B. O. Inerbaev, G. M. Goncharenko, V.S. Deeva, International Journal of Recent Technology and Engineering, 8 (4) (2019)

8. I. P. Prohorov, V. N. Lukyanov, A. N. Pikul, Izvestiya TSKHA, 4 (2014)

9. A. M. Gataulin, System of applied statistical and mathematical methods for processing experimental data in agriculture (Moscow: Publishers MSKHA, 1992) 